\title{
THE DEVELOPMENT OF JATILUWIH MICRO- HYDRO POWER PLANTS TO SUPPORT TOURISM DESTINATIONS
}

\author{
Putu Diana Sari \\ Department of Electrical Engineering \\ Udayana University \\ Bali, Indonesia
}

\author{
I N S Kumara \\ Department of Electrical Engineering \\ Udayana University \\ Bali, Indonesia
}

\begin{abstract}
Jatiluwih is one of 18 villages located in Penebel District, Tabanan Regency. Jatiluwih has extensive agricultural land and is known for its beauty and natural terraces. The lack of public facilities such as lighting lamps located along the Subak Jatiluwih road is due to the electricity network not yet entering the Subat Jatiluwih area. With the existence of Korsorsium between Toyama Government and Bali Provincial Government, Tabanan Regency Government, and Udayana University CORE, power plants were built using renewable energy, namely water. The consortium conducts research related to the construction of a micro hydro power plant (PLTMH) in the Subak channel (irrigation) which is then utilized for public facilities namely street lighting lights around the Subak area. The PLTMH Jatiluwih was built on four sites or locations, namely Site 2 which consists of Site 2-1 PLTMH type Run Off River using Archimedes turbine and Site 2-3 Run Off River PLTMH using open water turbines with a second generation capacity of $1.5 \mathrm{~kW}$ , Site 7 MHP type Run Off River uses an open water turbine with a generating capacity of 500 Watts, and Site 5 uses penstock with a generating capacity of $7.5 \mathrm{~kW}$.
\end{abstract}

\section{Keywords-micro-hydro powerplant, Subak Jailuwih}

\section{INTRODUCTION (HEADING 1)}

In Bali, mini-hydro and micro hydro potential of $15 \mathrm{MW}$. [1]. Indications Mini and Micro hydro powerplant Capacity Supply Plan per Province in 2015-2025, the total installed capacity of Bali Province in 2025 is targeted to 23.5 MW [2].

To achieve the development goals mini-hydro and micro hydro power plant activities, such as increasing the quality and quantity surveying the potential energy of water power and perform detailed mapping for the development of hydro power small scale and improve the implementation of legislation regarding the purchase of electricity from hydropower plants with capacity up to $10 \mathrm{MW}$ by PLN [2].

Jatiluwih is one of the 18 villages located in Penebel District Tabanan regency. Jatiluwih has a fairly extensive agricultural land and is renowned for the beauty and scenery natural terraces. With a fairly extensive agricultural land hence irigari system governed by an autonomous organization which is often called Subak. Subak Jatiluwih famous beauty and naturally landscaped terraces Jatiluwih Subak make tourist destinations in Bali. The lack of public facilities such as lights that are along the road Subak Jatiluwih it is because the electricity network has not yet entered the Jatiluwih Subak area.

With the Korsorsium between the Government Toyama Bali Provincial Government, the Government of Tabanan, and Universitas Udayana, they built a Micro Hydro Power (MHP), which utilizes the irrigation canals that were in Subak Jatiluwih. This paper aims to describe the design and performance of technical specifications of the MHP.

\section{LITERATURE REVIEWS}

\section{A. Subak}

In Bali, there is an autonomous organization that houses these canals, the Subak. In agriculture, Subak is an organization that is carrying out traditional irrigation as well as being part of a culture that is passed down through the generations by the people of Bali. According to the Bali Provincial Regulation No. 9 In 2012, Subak is a traditional organization in the areas of water use and or layout of plants at the farm level to the indigenous people of Bali who are sosioagraris, religious, economic and historically continues to grow and develop.

\section{B. Micro Hydropower Plant}

Micro hydro power plant (MHP) is a small scale power plants that use hydropower as its driving, such as irrigation canals, rivers or natural waterfall, by utilizing high waterfall (head, in meters) and the amount of water discharge $(\mathrm{m} 3 / \mathrm{s})$, Usually the kinetic energy or potential energy of water is converted into electrical energy through the conversion tool (turbine and generator) which is then distributed to consumers.

\section{Scheme-scheme MHP}

1. Run Off River

In this scheme partial discharge water flowed through canals and pipes to the turbine. In this scheme there is no water storage. The advantage of this scheme is easy 
to manufacture, more durable, and do not disrupt aquatic ecosystems. Disadvantages of this scheme is the lack of water supplies so that when the dry season water flow to the turbine supply will be reduced.

2. storage

In this scheme the water flow is stopped by the dam. Thus, water is stored in reservoirs. The advantage of this scheme is the presence of water reserves that could be used at any time. The disadvantage is the dam could damage aquatic ecosystems. In addition, after several years, it could be a lot of garbage piled up in the reservoir.

3. Integration

In this scheme the water flow is not accommodated as in storage. In contrast to the run-off river scheme which require the creation of new canals for mengarahan water to the turbine, this scheme utilizes existing canals, either an irrigation canal or water supply pipes.

\section{Components $M H P$}

MHP consists of components of civil and mechanical and electrical components, namely:

1. Civilian components: Diversion Dam, Intake (Canal Entry), Carrier Canals, Bak precipitator, Concrete drop Canals, Bath Calming, Sieve, Rapid Pipeline (Penstock), house plant, and Canal waster.

2. Mechanical and Electrical Components: Turbine, Generator, Electrical and Instrument Control Panel, and Load Ballast.

\section{POTENTIAL AND DEVELOPMENT HISTORY OF MHP}

In the village of Jatiluwih the majority community as farmers that have large farms and has organized irrigation system. In Bali, called Subak irrigation systems, water control system is an autonomous organization that regulates the irrigation system on the farm. Due to the vast agricultural land and produced unique view of the expanse of farmland that is shaped like terracing then be used as a Tourism Destination by the Government of the Tabanan Regency dikeloka by DTW (Destination Region) Jatiluwih.



Fig.1 Subak Jatiluwih village

With the development of Jatiluwih Subak as a tourist area but is inversely proportional to the existing public facilities. The lack of public facilities such as street lighting around Subak Jatiluwih due to the lack of electricity that passes through the network Subak Jatiluwih area. With the potential of renewable energy that the water flow in the canal Subak (irrigation) Jatiluwih so further development.

The development is carried out by a consortium between the Government of Japan Toyama with the Provincial Government of Bali, Tabanan District Government, and CORE Udayana University, he built a power plant using renewable energy: water. The consortium is conducting research related to construction of micro hydro power (MHP) in the canal Subak (irrigation) that is then used for public facilities, namely lamp street lighting in the surrounding area of Subak.

The consortium has conducted research that began in 2014, this study is the potential possessed by Desa Jatiluwih while increasing tourist attraction in the area. Potential Subak has a constant water flow into one idea of the construction of the MHP. Which is another factor of course the construction MHP Head and Debit, followed by the Subak canal karakteristrik. After research showed as many as ten Site or point potential construction of MHP. And further investigation it obtained seven sites with the most potential, but approved and can be funded by JICA just four Web only, ie Site 7 in Tempek Subak Telabah Gede, Site 2 in Tempek Subak Umadwi, and Site 5 in Tempek Subak Umakayu,

The MHP development projects implemented by the communities Subak Jatiluwih and Japanese engineers from the Company Suikikogyo. MHP construction began in May 2017 until the inauguration in November 2017. The electricity generated by the MHP used as lighting the lamp at the jogging track around the water control system and lighting at Temple Bedugul and Subak. In March 2019 will be paired with rice milling machine as the load on the Site 5. Until now the MHP managed by Subak and still overseen by the technicians of the Company Suikikogyo Japan.

\section{Micro Hydro POWER Plants EACH Site}

There are two types of operation of the MHP, which automatically and manually.

\section{Automatic Operation}

- $\quad$ Replacing the battery charging load according to the conditions.

- When the voltage drops (less than 95 volts), the load connection is disconnected to prevent excessive electrical discharges of the battery

- When the voltage rises (over 130 volts), an electrical discharge load connected to prevent overcharging the battery. In this case canaled to Heater is located next to the control panel.

- When abnormal electrical discharges, connect the load to prevent excessive battery charging.

- $\quad \mathrm{ON} / \mathrm{OFF}$ the load carried by the Timer.

2. Operation Manual

- $\mathrm{ON} / \mathrm{OFF}$ is done manually by moving the ON / OFF switch. 
- Protection device electrically batteries do not work.[3]

The working principle of the MHP together with the MHP in general, ie the mechanical energy is converted into electrical energy, the water discharge affects the rotational speed of the turbine so that the electrical energy generated varies depending on the flow of water flowing. The turbine is connected directly to the generator using the connecting shaft and chain, so that when the turbine rotates due to the flow of water through the turbine generator will then automatically rotates and generates electricity alternating then rectified through the rectifier and stored in the battery wet.

\section{A. Site 2-1}

Micro-hydro power plants on the 2-1 manifold Site Run Off River, the type of plants without the use of bath water Shelter but there is a new canal that directs water to the turbine. Have a capacity of up to $1 \mathrm{~kW}$ and the resulting generation output of 400 Watts.

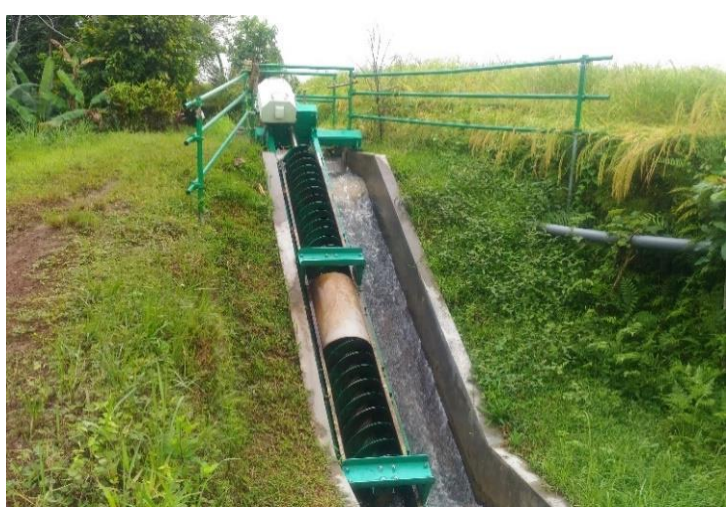

Fig.2 MHP at 2-1 Site

The main components contained in the Site MHP 2-1 including water turbines, chain and connecting shaft, and a generator. Turbines are used on the site is a type of turbine 2-1 Archimedes spiral which has an elongated shape. Turbine generator directly connected through the use of a drive shaft and bearing unit. Here are the specifications of the turbine mounted on Site 2-1:.

Table 1. Specifications 2-1 Turbine Site

\begin{tabular}{|c|c|}
\hline $\begin{array}{c}\text { Turbine or Air Turbine } \\
\text { Type }\end{array}$ & $\begin{array}{c}\text { Spiral Water Turbine / turbine } \\
\text { Archimedes }\end{array}$ \\
\hline Total Water Use & $0.03 \mathrm{~m} 3 / \mathrm{s}$ \\
\hline Effective heights & $2,5 \mathrm{~m}$ \\
\hline Power efficiency & $55 \%$ \\
\hline output Generation & $0.4 \mathrm{~kW}$ \\
\hline Diameter Water Turbine & $0.47 \mathrm{~m}$ \\
\hline
\end{tabular}

The generator used is small 3 phase AC generator that is often used in wind powerplant, HG-350 series of SKY Electronics that have a capacity of $1 \mathrm{~kW}$. Generator is connected directly to the turbine via the shaft and the bearing so that when the turbine rotates, the generator will rotate. Here are the specifications of Generator HG-350:

Table 2. Specifications generator SKY HG350

\begin{tabular}{|l|l|l|l|}
\hline output & $1 \mathrm{~kW}(300 \mathrm{rpm})$ \\
\hline $\begin{array}{l}\text { external } \\
\text { Dimension }\end{array}$ & $\varphi 353 \mathrm{mmx} 102 \mathrm{~mm}$ \\
\hline $\begin{array}{l}\text { structure } \\
\text { Number of Poles }\end{array}$ & $\begin{array}{l}\text { Rare earth permanent magnet rotor type } \\
\text { axial outer form, Coreless structure }\end{array}$ \\
\hline $\begin{array}{l}\text { magnet Materials } \\
\text { Rare earth magnets }\end{array}$ & \\
\hline Number of Coils & 30 pcs (10 pcs / 3phase) & $300 \mathrm{rpm}$ \\
\hline RPM & $100 \mathrm{rpm}$ & $200 \mathrm{rpm}$ & 179.1 \\
\hline \begin{tabular}{l} 
voltage (V) \\
\hline \begin{tabular}{l} 
Current (A) \\
\hline
\end{tabular}
\end{tabular} & 60.2 & 120.4 & 5.99 \\
\hline
\end{tabular}



Fig. 3 Air Canals 2-1 MHP Site

(Source: Manual Book Site Suikikogyo 2-1, 2017)

\section{B. Site 2-3}

Just as the MHP at 2-1 Site, the Site 2-3 using this type of Run Off River. Site 2-3 using open water turbines, water turbine as in the form of water turbine pda general. Site of generation capacity at 2-3 is 500 Watts and output of 160 Watts. When combined with the 2-1 Site generating capacity at Site 2 is $1.5 \mathrm{~kW}$.



Fig.4 MHP Sie 2-3

The main components 2-3 MHP Site consists of a water turbine, generator, chain link, and sinker. In contrast to the MHP at 2-1 Site, the Site 2-3 if a large water flow or flood 
would turbines will stop spinning this case because their wings in the form of wood on the canal that flows into the water turbine, if the discharge excess water then will be pushed by the water wing and automatically turbine rises so the turbine will float because of their weight. If the water flow is small then the two canals in addition to the overflow of the water turbine will be shut down so that the water will only flow into the turbine canal only.

Table 3 Specifications 2-3 Turbine Site

\begin{tabular}{|l|l|}
\hline $\begin{array}{l}\text { Turbine or Air Turbine } \\
\text { Type }\end{array}$ & Open Air Turbine \\
\hline Total Water Use & $0.03 \mathrm{~m} 3 / \mathrm{s}$ \\
\hline Effective heights & $1 \mathrm{~m}$ \\
\hline Power efficiency & $55 \%$ \\
\hline output Generation & $0.16 \mathrm{~kW}$ \\
\hline Diameter Water Turbine & $1.2 \mathrm{~m}$ \\
\hline
\end{tabular}

Subak canal used by the MHP Web Site 2-1 and 2-3 the same, but the only difference being the canal towards the head water turbine and water turbine individual is different. This is exactly consider the selection of appropriate forms of turbines at each site, so the capacity installed in the Web Site 2-1 and 23 are different. So that the generator is used also have different models. On Site 2-1using SKY HG-350, Site 2-3 using SKY HR-300. Generator capacity installed in the Site 2-3 is 500 watts, while the maximum output of 160 Watt obtained. Here are the specifications Generator SKY HR-300:

Table 4 Generator Specifications SKY HR-300

\begin{tabular}{|c|c|c|c|}
\hline output & \multicolumn{3}{|c|}{$500 \mathrm{~W}(300 \mathrm{rpm})$} \\
\hline external Dimension & \multicolumn{3}{|c|}{$\varphi 303 \mathrm{mmx} 96 \mathrm{~mm}$} \\
\hline structure & \multicolumn{2}{|c|}{$\begin{array}{c}\text { Rare earth permanent magnet } \\
\text { rotor type axial outer form, } \\
\text { Coreless structure }\end{array}$} \\
\hline Number of Poles & \multicolumn{3}{|c|}{ 40 Poles } \\
\hline magnet Materials & \multicolumn{3}{|c|}{ Rare earth magnets } \\
\hline Number of Coils & \multicolumn{3}{|c|}{30 pcs (10 pcs / 3phase) } \\
\hline RPM & $100 \mathrm{rpm}$ & $200 \mathrm{rpm}$ & $300 \mathrm{rpm}$ \\
\hline voltage $(\mathrm{V})$ & 58 & 117 & 174.1 \\
\hline Current $(\mathrm{A})$ & 0.97 & 1.96 & 2.92 \\
\hline output $(\mathrm{W})$ & 56.1 & 229.4 & 507.7 \\
\hline
\end{tabular}




\begin{tabular}{|l|l|}
\hline Turbine or Air Turbine Type & Open Air Turbine \\
\hline Total Water Use & $0,014 \mathrm{~m} 3 / \mathrm{s}$ \\
\hline Effective heights & $2.1 \mathrm{~m}$ \\
\hline Power efficiency & $55 \%$ \\
\hline output Generation & $0.16 \mathrm{~kW}$ \\
\hline Diameter Water Turbine & $2,5 \mathrm{~m}$ \\
\hline
\end{tabular}

Generators are used at Site 7 the same as that used on the Site generator 2-3, the SKY HR-300. Generator capacity installed in the Site 2-3 is 500 watts, while the maximum output of 160 Watt obtained. Specifications of Generator SKY HR-300 can be seen in Table 3.4. generators are used together because of generation capacity at 2-3 Site and Site 7 equal, and therefore used the same type of generator.

\section{Site 5}

In contrast to the three previous sites, Site 7, Site 2-1 and 2-3 at Site 5 Site using penstock pipe as a medium for distributing water to the turbine. Besides a water turbine at Site 5 were in the middle of the penstock pipe. Installed capacity at Site 5 was the largest that is $7.5 \mathrm{~kW}$. That is because a very large flow of water is constantly flowing due to Site 5 adjacent to the springs (Beji, a term in Bali). With a capacity of $7.5 \mathrm{~kW}$ can produce a maximum output of $4.9 \mathrm{~kW}$.



Fig.7 Site 5 with Control Panel

Because it is in the pipeline, water turbines are used must have specifications different from the three previous site. On Site guide books mentioned turbine 5 used propeller type turbine water inside the pipe. Here are the specifications of water turbines used at Site 5:

Table 6 Specifications Turbine Site 5

\begin{tabular}{|l|l|}
\hline $\begin{array}{l}\text { Turbine or Air Turbine } \\
\text { Type }\end{array}$ & Air Turbine Propeller \\
\hline Total Water Use & $0.07 \mathrm{~m} 3 / \mathrm{s}$ \\
\hline Effective heights & $12 \mathrm{~m}$ \\
\hline Power efficiency & $60 \%$ \\
\hline output Generation & $4.9 \mathrm{~kW}$ \\
\hline Diameter Water Turbine & $150 \mathrm{~mm}$ \\
\hline
\end{tabular}

From Table 6, it can be seen head and water flow is greater than the three previous site. With a debit and a great head of course full capacity at Site 5 greatest, $7.5 \mathrm{~kW}$. Besides the construction of the MHP at Site 5 is very different from other sites. Using the penstock pipe as an intake canal and there is a turbine or Flow Screen. Flow screen is at the tip of the pipe pensctock, water enters through a screen flow is then canaled to a turbine which is in the pipeline in nature. Water turbine is connected directly to the generator using the connecting shaft as Site 2-1, but at Site 5 does not use a chain.

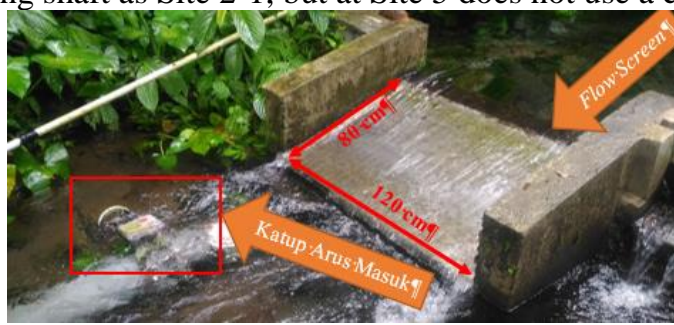

Fig. 8 Flowscreen and Valves Inflows Site 5

Pipes used has a diameter of $30 \mathrm{~cm}$ with a length of \pm $15 \mathrm{~m}$. Fortunately connecting pipes used some kind of ring or rings. Water turbine is connected directly to the generator using the connecting shaft. Generator used has a capacity of $7.5 \mathrm{~kW}$ with a brand Fukuta originating from Taiwan, in contrast to previous generator that sites that originated in Japan due to the capacity used is not available. Here are the specifications of the generator is used at Site 5:

Table 7 Generator Specifications Fukuta PSEF 112X

\begin{tabular}{|l|l|}
\hline output & $7.5 \mathrm{~kW}$ \\
\hline Nominal Torque (Tn) & 79.6 \\
\hline RPM & $900 \mathrm{rpm}$ \\
\hline Voltage (V) & 224 \\
\hline Current (A) & 19.5 \\
\hline & \\
\hline & \\
\hline & Turbin-Air \\
\hline
\end{tabular}

Fig. 9 Shaft Connecting an Turbine Generator

The working principle of the MHP at Site 5 is a flow of water will go through a screen and then distributed using penstock pipe, the inflow to the penstock pipe can be arranged with the intake valve. If the intake valve opens fully rotated then the flow of water flowing into the pipeline will be the maximum. Then the water flows downward along the \pm 15 meters. Before passing through the turbines the water contained adjustment valve to regulate flow and pressure of water that will pass through the turbine, after passing through the turbines, the water will dsalurkan into the overflow pipe located on the side of the turbine. The mechanical energy generated by the rotation of the turbine is converted into 
electrical energy. Their adjustment valve and pressure indicators affect the voltage issued by the generator.

\section{E. And Load Control System}

MHP operating system have in common is each site can be operated manually and automatically. Automatic in question is able to adjust the current system of abnormal conditions that occur in the generation system, like the flow of water decreases or increases, the damage to the component, and the presence of external interference. The control system used is the same each Site. Each site has a control panel that different, except in Site 2, which is a combination of the Web Site 2-1 and 2-3. The control system is what will control all of the operation, the generation and protection that exist in the MHP and the load.

On the control panel there are several indicator lights that mark ternyadinya abnormality, the operation of the load, and the power indicator of the generator voltage. Paperless Recorder used to store the value of output voltage and current of the generator.



Fig. 10 Indicators on the Control Panel

MHP Jatiluwih is used to supply the load in the form of street lighting that was around a few Tempek Subak. Load operation is performed automatically by using a timer. Previously generated electricity stored in a battery whose numbers 9 units each Site. The lights used are LED bulbs with power 10 Watt. The overall number of lights used \pm 78 lights.

By using a timer, the lights $\mathrm{ON}$ automatically ie at 18:00 to 21:00 and 04:00 to 06:00, outside of these hours will load OFF.

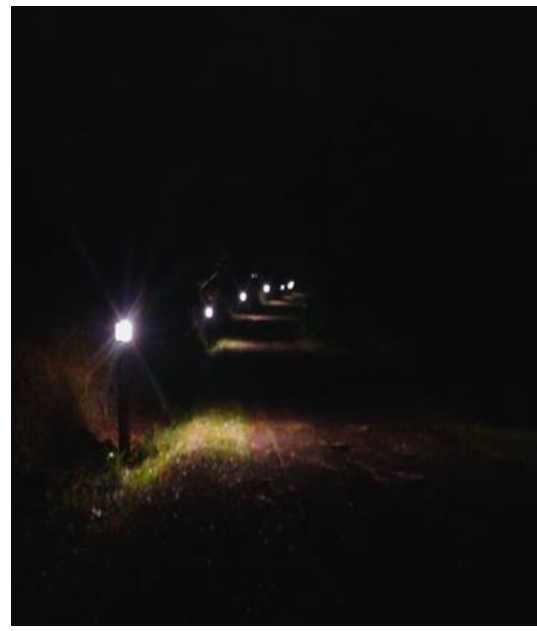

Fig. 11 Load at Night

\section{CONCLUTION}

The consortium between the Government of Toyama Japan and the Provincial Government of Bali, the Tabanan Regency Government, and the CORE of Udayana University, has developed PLTMH in Jatiluwih Village with financial support from JICA which is used for street lighting around Subak Jatiluwih.

The consortium has built PLTMH Jatiluwih on four sites or locations, there are Site 2 which consists of Site 2-1 PLTMH type Run Off River using Archimedes turbine and Site 2-3 PLTMH type Run Off River using open water turbines with both generating capacity is $1,5 \mathrm{~kW}$, Site 7 Run Off River type MHP uses an open water turbine with a generating capacity of 500 Watts, and Site 5 uses penstock with a generating capacity of $7.5 \mathrm{~kW}$.

\section{REFERENCES}

[1] Directorate General of New Renewable Energy and Energy Conservation, Statistics Book of New, Renewable Energy and Energy Conservation 2016, Jakarta, December 2016.

[2] Republic Indonesia, General Plan Of National Energy, Jakarta, 2015.

[3] Suikikokyo, Manual for Microhydro Power Plant System (PLTMH) at Indonesian Water Canals. Tokyo : Suikikogyo, LTD, 2017.

[4] Suikikokyo, Book Explanation of Site 2-1, Site 2-1, Site 5, and Site 7 Operating Methods, . Tokyo : Suikikogyo, LTD, 2017

[5] IMIDAP.. Book 2 C Electrical Mechanical Feasibility Study Guidelines, Print 1. Jakarta: Directorate General of Electricity and Energy Utilization Ministry of Energy and Mineral Resources. 2009

[6] IMIDAP. Microhydro Operator Training Module. Print 1. Jakarta: Directorate General of Electricity and Energy Utilization Ministry of $\begin{array}{llll}\text { Energy and } & \text { Mineral Resources. }\end{array}$ 